\title{
Money, Income and Currency Substitution: Evidence from Three Countries
}

\author{
Dallas S. Batten and R. W. Hafer
}

S

NUMBER of studies have demonstrated a relatively close empirical relationship between changes in a transaction-based measure of money and changes in nominal income. This relationship, found for a variety of economies, suggests that monetary policymakers can directly influence the path of nominal income over time by changing the growth of the domestic money stock.'

It has been argued recently, however, that the relationship between domestic money growth and economic activity may be affected by extemal factors." If domestic residents consider domestic and foreign currencies (or other financial assets) as relatively close substitutes, for example, then changes in relative preferences for domestic and foreign assets will motivate them to reallocate their portfolios. This portfolio adjustment will affect the domestic demand for all assets, including domestic money." This hypothesis, known as currency substitution, suggests that, if the demand for domestic money is dependent inter alia on external factors, domestic money growth may not affect domestic economic activity to the degree anticim pated by policymakers.

This article tests whether currency substitution has affected the relationship between domestic money

Dallas S. Batten and R. W. Hafer are research officers af the Federal Reserve Bank of St. Louis. Paul G. Christopher provided research assistance. The authors would like to thank Jeff Bergstrand for his comments.

'See, for example, Batten and Hater (1983).

¿See Miles (1978), Brittain (1981) and McKinnon (1982).

${ }^{3}$ Within this context, one of the initial approaches to the investigation of currency substitution was within a money demand framework. See Batten and Hafer ( $\$ 984 a$ ) and the references contained therein.

and economic activity (incomel in the United States, Germany and Japan within the framework of a simple reduced-form model. These countries were chosen primarily because they are the most infuential in international financial markets: indeed, some have suggested that their monetary policy actions should be coordinated. ${ }^{+}$A reduced-form model is used, because it is a convenient form for testing the relative impact of specific variables on economic activity. A sufficient condition for currency substitution to be important is that some measure of foreign influence money growth or exchange rate movements - have a significant impact on domestic income after accounting for the impact of domestic money growth."

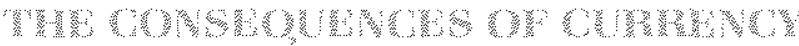 BUDSRTWWTH}

In a world of freely floating exchange rates, domestic monetary authorities theoretically are insulated from monetary shocks from abroad. Because mone tary authorities have no obligation to maintain their currencies' foreign exchange value, an expansion or contraction of one country's money supply does not necessitate automatic policy reactions by other nations. Instead, exchange rates fluctuate in response to relative movements in money supplies. Thus, monetary actions in one country do not necessarily impinge on the policy actions of another; each country is able to pursue its own domestic policy program.

${ }^{4}$ This policy coorotination scheme is atiributed to McKinnon (1984).

5This condition is only sufficient in that foreign influences may affect domestic activity within the structural econometric specification, but may not be identifiable in the reduced-form specification that we thave employed. 
Some analysts argue that this insular propery of floating exchange rates breaks down when there is cureney substitution. If domestic residents hold portfolios containing both foreign and domestic assets and reallocate these portiolios according to changes in the relative opportunity costs domestic ws. foreign of these assets, foreign monetary shocks will alter the relative costs of holding a given portfolio and induce residents to reallocate their portfolios between domestic and foreign assets. This behavior changes the demand for domestic money and, as a resull, changes the impact of any specific domesic money growth rate on the domestic economy. As one advocate of the currency substitution hypothesis has noted.

.. currency substitution destabilizes the demand for individual national monies so that one can't make much sense out of year-to-vear changes in purely national monetary aggregates in explaining cycles in purely national rates of inflation. ${ }^{6}$

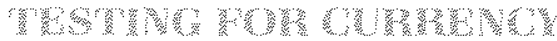

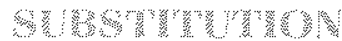

Alhough several approaches have been used for tests of currency substitution, this article focuses on the impact of external factors on the velocity of domestic money, that is, the relationship between domestic money growth and the growth of nominal income? In previous reseach, Radcliffe, Warga and Willett (1984) and Mckinnon (1984) have emploved a reduced-form model of domestic income growth to test for currency substitution with conflicting results: Radcliffe, Warga and Wilet find litle empirical stpport for the curency substitution hypothesis, whle Mckinnon finds that extenal factors have a rather substantial impact on U.S. economic activity, Both analyses, however, were conducted using annun data over the relatively short floating exchange ate period, 1972-83. Such a limited sample $(12$ observations de-

ackinnon (1982), p. 320 .

7For example, Miles mestigates this issue through a CES produc. tion function in which monetary services are "produced" by both domestic-currency and foreign-currency real balances. The degree of currency subsitution was measured by the elasticity of substitution between these two balances.

A second approach, mentioned above (fin. 3), is to examine whether the domestic demand for money is a function of external and internal tactors. A thitd approach is to ask whether the rate of domestic inftation is dependent upon external factors (see Mckinnon (1982)). Fhis approach has been criticized by Batten and Hafer (1984b) and Radcliffe. Warga and Witlett (1984). In this article, we have chosen a fouth approach, which is to invesigate the signifi. cance of external factors on the growth of domestic income using a simple reduced-form model. creases the power of he station test and thereho the confinence one can place in the results.

The tests conducted here extend heir andyses in

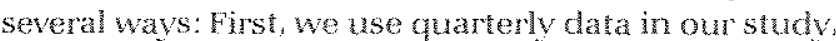
which expards the sample for the lowing exchange rate period to about 50 observations. Second, we specify a more complete rediced-fom model betore resting for the intuence of international factoss. tn a previous paper, Batten and $\mathrm{H}$ afer $\{1983\}$ demonstreted that variables other than domestic money growh alone explain some of the varation in income growth across countries. Consequently, in addition to money growth, we test for the imporance of including a measure of govermment expenditures as well.

\section{berase Comera

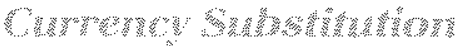

There is no consensus on the approprate variable with which to caplume the foreign influence presuned in the hypothesis of cumency substimtion. Mckinmon 1982 argues that since the demand for word monev cannot be affected by changing compositions of inter. national portolios, the wond money supply tor, alterwatively, the domestic money supply pus the rest-otword money supply is a beter predicton of chmestic economic activity than domestic money growh alone." An obvious phobm whth employing the growth rate of "world money" as a proxy for foreign influences is that it nay simply refect wond economic activity that already affects the domestic econony though the nomal channels of international trade. Specifically, an increase in meigh money growt may stmulate foretgr demand for all goods and services, induding the exports of the domestic country In other words, allhough chages in the world money supply may appear to affect the domestio economy statistically, this result does not necessa?" ily refect curreney substiunon.

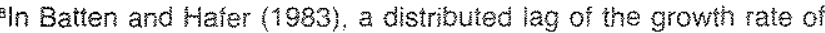
expots also was included. This measure is not included in this study, however, to ensure that all of the breion influences are being captured by the variades proxying for currency substiution. This may bias the test but it does so in tavor of finding a significan inpact of curetcy substitution. When a distritured lag of expont growth is added to equation , no evidence of currency substitution can be found. Conseguenty, as discussed below, the variables that have boen offered as proxies for currency substitution may also reflect the impact that intemathonal trade has on domestic economic activity.

9Mckinnon (1982) provides a raticnale ior emoloving the world money supply in liev of any particutar domestic money supply. Goldstein and Haynes (1984) and Spinell (1983) aroue that the approprate test must involve the separaton of the world money supply into ils domestic and rest-of-worto components.
} 
In response to this line of criticism, Mckinnon 1984 claims that the effective exchange rate is a preferable measure in tests of currency substitution." In particular, he employs changes in the foreign exchange value of a currency as an indicator of changes in domestic money demand prompted by currency substitution.

There are, however, at least two objections to using changes in the effective exchange rate as a proxy for foreign-generated disturbances to domestic money demand." First, exchange rates move in response to changes in both the domestic demand for money and real economic conditions, such as a supply shock." Such changes in real conditions motivate changes in the relative price of one country's output in terms of the output of other countries, that is, a change in the relative price of traded to nontraded goods. Second movements in the exchange rate also reflect changes in (1) the foreign demand for foreign money and (2) the policies followed by foreign monetary authorities. Furthermore, exchange rate stability may be a policy goal for some monetary authorities. Consequently exogenous exchange rate movements may cause domestic policymakers to react and, hence, may affect domestic money growth. ${ }^{13}$

In sum, exchange rate changes frequently are motivated by events quite apart from curency substitum tion's impact on domestic money demand. Moreover; it is impossible to distinguish exchange rate movements due to these events from those due to changes in the demand for domestic money. These reservations should be kept in mind when assessing the empirical impact of these variables on the relationship between domestic money and domestic economic activity.

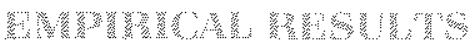

The empirical model suggested in the preceding section takes the general form

(1) $\dot{\gamma}_{t}=\alpha+\sum_{i=0}^{I} \beta_{i} \dot{M}_{t-i}+\sum_{j=0}^{J} \lambda_{i} \dot{G}_{1-i}+\varepsilon_{1}$,

10 The effective exchange rate is the International Monetary Fund's 17 -country exchange rate index with the weights derived from the IMF's multilateral exchange rate model. For details on its construction, see Artus and McGuirk (1981).

${ }^{t}$ See, for example, Mussa (1981).

:2White real shocks do affect the demand for money through their impact on real income, they also aftect relative prices and, hence, have independent effects of their own on exchange rates. See Stockman (1980).

Mn this point, see Batten and Ott (1984). where $\dot{Y}$ represents the annualized quarterly growth of domestic nominal income, $\dot{M}$ is the anmulatod quarterly growth of the narrowly defined domestic money stock (M1), and $\dot{G}$ is the annualized quarterly growth of government expenditures. ${ }^{1+}$ The terms $\alpha, \ddot{\beta}$ and $\lambda$ are parameters to be estimated and $\varepsilon_{1}$ is an error term with the usual properties assumed.

Equation 1 represents the domestic reduced-form equation to which the variables that measure foreign influences can be added to test for the impact of currency substitution. Before such a test is conducted, however, the appropriate lags, I and J, must be determined. To do so, we use Akaike's final prediction erros (FPE) criterion." This criterion is based on a mean square error prediction norm and, therefore, may select lag structures that are not statistically significant using conventional significance levels.

Equation 1 was estimated over the period 11/1972II/1984 (IIL/1972-IV/1983 for Japan) using the FPEselected lag structures. The regression results for the United States, Gemany and Japan are reported in table 1. The U.S. results for money growth are faily similar to those found by other studies: the summed effect of a change in money growth is significant and is not different statistically from unity $\{t=0.11$. Within the framework of this reduced-form specification, changes in the growth of govermment expenditures have no impact on economic activity in the United States: the fPE criterion selected no lag structure for this variable.

The results for Germany also show money growth to have a significant long-run effect on income growth: the reported sum coefficient is 0.522 . It is interesting to note that while the FPE procedure selects a relatively long lag for government expenditures, its cumulative impact is not statistically significant at the 5 percent level. These results are broadly consistent with those reported in Batten and Hafer $(1983)$.

Finally, for Japan, the FPE procedure selects six lags on money growth and three lags on government expenditure growth. The results in table 1 indicate that both the cumulative impact of money growth and

\footnotetext{
${ }^{14}$ To remove the impact of cyclical changes, cycle-adjusted government expenditures could be employed to measure fiscal actions in the estimation of equation 1 for the United States. Because comparable measures of goverment expenditures are not avaliable for Germany and Japan, federal government expenditures not adjusted for cyclical changes are employed for each country. If should be noted, however, that he results for the United States were invariant to the government expenditures series used.

${ }^{15}$ See Batten and Thomton (1984) for a discussion and application of this criterion.
} 
Table 1

\section{Regression Estimates of Equation 1}

\begin{tabular}{|c|c|c|c|c|c|c|}
\hline \multirow[b]{2}{*}{ counirysample } & \multicolumn{3}{|c|}{ Estimated Coefficients (lags) tor } & \multicolumn{3}{|c|}{ Summary Statistics? } \\
\hline & Constant & M & ब & $\vec{A}^{2}$ & SE & DW \\
\hline $\begin{array}{l}\text { United States. } \\
\text { (11972-11/984) }\end{array}$ & $\begin{array}{l}317 \\
(939)\end{array}$ & $(0,965)$ & & 0,14 & 459 & 161 \\
\hline $\begin{array}{l}\text { Germany } \\
(11972-1 / 1984)\end{array}$ & 035 & $(0.523:(6)$ & $\begin{array}{l}0.200(8) \\
(133)^{\prime}\end{array}$ & 0.41 & 354 & 216 \\
\hline (10pan $1972-14(983)$ & $\begin{array}{l}0,10 \\
0.08)\end{array}$ & $(6,602 \%(6)$ & $(2,225)$ & 0,74 & 3.48 & 185 \\
\hline
\end{tabular}

S Statistically significant at the 5 percent level

Only summed coeflicients are reported. Absolute values of I statistics shown below each coefficient.

F': is the coeficient of detemination adjusted for degrees of treedom, SE s the regression standard error, and DW is he DUrbin Watson test statistic:

the cumulative effect of government expenditure growth are significant. Moreover; the distributed lags on these variables alone explain almost 75 percent of the variation of nominal income growth during this period. This is five times the explanatory power of the U.S. equation and 80 percent more than the German equation.

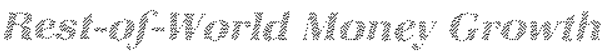

The first proxy used in our test for currency substitution is the rest-of-world money stock (ROWM). In tests of currency substitution, it is assumed that the demand for world money is stable and changes in ROWM reflect substitution from the domestic currency to foreign currencies. For example, an increase in the growth rate of RowM reflects a shift from domestic to foreign money, signalling a decrease in the demand for domestic money or, equivalently, an increase in its velocity. That is, increases (decreases) in ROWM growth should increase (decrease) the rate of growth of domestic income, ceteris paribus.

Two approaches can be taken to measure ROWM both of which require some aggregation assumptions. One procedure, suggested by Mckinnon 11982 , 1984), uses the money growth rate series for each country in the rest-of-world sample to calculate a weighted average growth rate. In calculating this series, the individual country's weights are determined using the country's share of world nominal GNP in some base year. where world GNP and each country's GNP are specified in U.S. dollars. By using this fixed-weight approach, complications arising from continually fluc- tuating exchange rates are avoided. In the discussion that follows, this series is referred to as ROWMF.

An alternative to the fixed-weight approach is to convert all foseign money supplies into the relevant domestic currency equivalents, sum the values for each county to form a rest-of-world monetary aggregate, then calculate the latter's growth fate. This approach, advocated by Spinelli (1983), allows the relative country weights to vary across the sample period as exchange rates fluctuate. This series is referred to as ROWMV.

The ROWM growth series were generated using the country sample of Belgium, Canada, France, Germany, Italy, Japan, the Netherlands, Switzerland, the United Kingdom and the United States. Obviously, the ROWM growth series for each country uses the summed money supplies of the other countries in the sample.

To test statistically for the importance of ROWM growth on domestic income growth in the United States, Germany and Japan, a distributed lag of ROWM growth foreach country has been added to equation 1. The FPE criterion then was applied to select the appropriate lags of each of the three variables $(\dot{M} 1, \dot{G}$ and ROWM simultaneously. The results using ROWMF growth are reported in table $2 . "$

\footnotetext{
${ }^{16}$ The regression results using ROWMF and ROWMV for the United States and Germany are based on slightiy different sample periods than those used in table 1 . Because of data restrictions in generating the ROWM measures, the sample period used for the United States and Germany is 11/1972-IV/1983. The analysis for Japan uses the sample period reported in table 1 .
} 
Table?

Testing the Significance of ROWM Growth: Fixed-Weight Version

\begin{tabular}{|c|c|c|c|}
\hline \multirow[b]{2}{*}{ Variable } & \multicolumn{3}{|c|}{ Estimated Coefficients (lags) for } \\
\hline & United States & Germany & Japan \\
\hline Constant & $\begin{array}{l}1588 \\
(0.58)\end{array}$ & $\frac{-9655}{(1.21)}$ & $=0.550$ \\
\hline $\mathrm{ZM}$ & $\begin{array}{l}0.925 \cdot(2) \\
(3.01)\end{array}$ & $\begin{array}{l}0.322^{*}(6) \\
(2.02)\end{array}$ & $\begin{array}{l}0.579^{9}(6) \\
(5.92)\end{array}$ \\
\hline $2 \mathrm{G}$ & 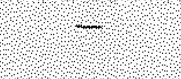 & $\begin{array}{l}0.158(8) \\
(1.20)\end{array}$ & $\begin{array}{l}0.2201(3) \\
(2.71)^{\prime}\end{array}$ \\
\hline ROWMF: & $\begin{array}{l}0.182 \\
(1.10)\end{array}$ & $\begin{array}{l}0.235 \\
11.231\end{array}$ & $\begin{array}{l}0.085 \\
10.431\end{array}$ \\
\hline Rownir, & & $\begin{array}{l}0.378^{\circ} \\
(2.03)\end{array}$ & $\begin{array}{c}-0.199 \\
(1.011)\end{array}$ \\
\hline nown?, & & & $\begin{array}{l}0.304 \\
(1.54)\end{array}$ \\
\hline ROWMF., & & & $\begin{array}{l}-0.570^{\circ} \\
(2786)\end{array}$ \\
\hline ROWMF, . & & & $\begin{array}{l}0.077 \\
(0.311\end{array}$ \\
\hline ROWMF : : & & & $\begin{array}{l}9.414 \\
(1.74)\end{array}$ \\
\hline Joint F (ROWMF) & -1 & 2.65 & 2.03 \\
\hline Summary statistic: & & & \\
\hline $\bar{R}^{2}$ & 0.15 & 0.54 & 0.78 \\
\hline$S E$ & 4.62 & 2,87 & 3,20 \\
\hline ow & 1,74 & 2.71 & 1,57 \\
\hline
\end{tabular}

Statistically significant at the 5 percent level.

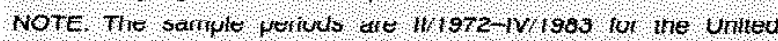
States and Germany $111 / 972$ - V 1983 for Japan Absolute value of t statistics shown below each coefficient

It is interesting to note that, when ROWMF growth was added to equation 1, the FPE procedure selected the same lag structures for domestic money and government expenditures for each country as those in table 1. It chose a lag length for ROWMF growth that was substantially different across the three countries, however. Even though these lag structures differ, the F-statistics the t-statistic for the United States) for testing the hypothesis that all of the estimated coefficients of nowMr growtl are zeru inclicate that this hypothesis cannot be rejected at the 5 percent significance level in any country examined." That is, ROWMF growth has no statistically significant impact on the growth of domestic income given the initial set of explanatory variables in equation 1. Moreover, the addition of ROWMF growth generally has little impact on the estimated coefficients of money growth and government expenditure growth. The one exception is money growth in Germany: when ROWMF growth is added to this equation - even though ROWMF growth is not statistically significant - the cumulative impact of domestic money growth declines by about 60 percent. ${ }^{.8}$

The substitution of the variable-weight calculation of ROWM growth for the fixed-weight version does little to alter the general results. These results, presented in table 3 , indicate that the distributed lag of ROWMV growth is not statistically significant at the $\mathbf{5}$ percent level in any of the three countries." Furthermore, the addition of ROWMV giowth has little inpact on the estimated sum coefficients of money and government expenditure growth. Thus, the results using ROWMV growth measure are consistent with those using ROWMF: there is little empirical support for the notion that foreign influences, measured by

"Omitting lags $t-4$ and $t-5$ on ROWMF for Japan had no impact on the conclusions. Also, when the contemporaneous ROWMF term for Germany was excluded, the coefficient on the $t-1$ term was $1 i^{2}$ longer statistically significant at the 5 percent level.

${ }^{18}$ This result may indicate that ROWMF is actually proxying for the impact of economic activity in the rest of the worid on German exports as discussed above. Indeed, when ROWMF is added to equation 1 augmented with a distributed lag of export growth, export growth is statistically significant, ROWM growth is not at any convontional lovol, and the summed offect of Cerman money growth is little affected.

t9lt should be noted that when ROWMV was added to equation 1 for the United States, the FPE criterion indicated a contemporaneous torm for government expenditures. Decause of this change, the $F$ statistic reported in table 3 for the United States compares the fit of the equation with $\dot{M} 1, \dot{G}$ and ROWMV to one that includes only contemporaneous and two lags on $\dot{M} 1$ and a contemporaneous term for $G$. When lags $t$ and $t-1$ on ROWMV for the United States are excluded, the coefficient of the $1-2 \mathrm{lag}$ remains statistically significant at the 5 percent level. Even though this may indicate that changes in ROWMV growth have some impact on U.S. economic activity, the inclusion of ROWMV has no impact on the influence of U.S. money growth. (Its summed effect remains esseritially one.) Furthermore, the estimated coefficient on ROWMV $\mathrm{tw}_{2}(.095)$ indicates that a 1 percentage-point change in ROWM growth has about one-tenth the impact on U.S. economic activity of a 1 percentagepoint change in U.S. money growth. Also. when ROWMV is added to equation 1 augmented with a distributed lag of export growth, export growth is statistically significant, while ROWMV is not at conventional significance levels. Consequently, the conclusions drawn in footnote 18 for Germany appear to be applicable for the United Slidites ds wetl. 
changes in foreign money supply measures, significantly impinge on for even add to the relationship between domestic money growth and income growth.

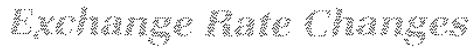

Changes in either measure of RowM growth may reflect phenomena other than those associated with currency substitution. Consequently, exchange rate (the foreign currency price of domestic currency) changes also have been employed as a proxy for currency substitution. In particular, a fall (rise) in the cxchange rate could indicate an increase (decrease) in the demand for foreign money relative to the demand for domestic money, that is, currency substitution. While exchange rates may change for other reasons, if currency substitution is the dominant force behind them, then observed exchange rate changes should be associated with opposite changes in the velocity of domestic money. A fall (rise) in the exchange rate, ceteris paribus, should cause the velocity of domestic money to rise (fall. Consequently, the same rate of dunestic noney growh slivald be assuctated will a higher rate of domestic income growth. If exchange rate movements are a proxy for currency substitution, these changes shmul have negative, statistically significant coefficients when added to equation 1.

To test this conjecture, a distributed lag of changes in the cffective cxchange rate is added to equation 1. The FPE criterion again is applied to select the lag structure for the three explanatory variables simultaneously. These results are presented in table 4 . The addition of the distributed lag of exchange rate changes has little impact on the lag length or the estimated coefficients for money growth and government spending growth in Germany and Japan. For the United States, on the other hand, this procedure selected a lag length of four on government expenditures where none had been selected before. The sum coefficient of this distributed lag of government spending growth, however, is not statistically significant at the 5 perent level Morenver, neither the lag length nor the estimated coefficients for money growth are affected significantly by the inclusion of exchange rate changes.

While the FPE procedure selected a relatively long lag of changes in the effective exchange rate for the United States, it selected only the contemporaneous term for Germany and Japan. The results for these two countries do not support the currency substitution hypothesis. The exchange rate coefficient is not statistically significant for Germany and, while significant

\section{Table 3}

Testing the Significance of ROWM Growth: Variable-Weight Version

\begin{tabular}{|c|c|c|c|}
\hline \multirow[b]{2}{*}{ Variable } & \multicolumn{3}{|c|}{ Estimated Coefficients (lags) for } \\
\hline & United States & Gemany & Japan \\
\hline Crnstant & $\begin{array}{l}0172 \\
(006)\end{array}$ & $\begin{array}{r}0609 \\
(0,39)\end{array}$ & $\begin{array}{c}0587 \\
(045)\end{array}$ \\
\hline $2 M$ & $\begin{array}{l}0.982^{*}(2) \\
(3.23)^{\prime}\end{array}$ & $\begin{array}{l}0.574(6) \\
(451)\end{array}$ & $(0,651 \%(6)$ \\
\hline 26 & $\begin{array}{l}0,15(0) \\
(155)\end{array}$ & $\begin{array}{l}0,116(8) \\
(0.85)\end{array}$ & $\begin{array}{l}0.238 \%(3) \\
(3.22)\end{array}$ \\
\hline nowuv & 0,004 & $\begin{array}{l}0,004 \\
(0,13)\end{array}$ & $\begin{array}{l}0.046 \\
(1,17)\end{array}$ \\
\hline nowm, & $\begin{array}{l}0,027 \\
0.67)\end{array}$ & $\begin{array}{l}0.050 \\
(1,49)\end{array}$ & $\begin{array}{l}-0,005 \\
(0.12)\end{array}$ \\
\hline Rownv, & $\begin{array}{l}0.085 \\
(221)\end{array}$ & & $\begin{array}{l}0076 \\
(1,78)\end{array}$ \\
\hline ROWMV, & & & 0.064 \\
\hline ROWMV, & & & $\begin{array}{l}0.022 \\
(0.49)\end{array}$ \\
\hline nowne, & & & 0.046 \\
\hline soint F (ROWMV) & 259 & 111 & 208 \\
\hline \multicolumn{4}{|l|}{ Summany statistics } \\
\hline$\vec{R}$ & 023 & 0.49 & 078 \\
\hline$S E$ & 4,40 & 3,01 & 3,19 \\
\hline DW & 174 & 240 & 217 \\
\hline
\end{tabular}

Statistically significant at the 5 percent level

NOTE The sample periods are $1 / 1972 \mathrm{~W} / 1983$ for the United States and Germany, $11 / 1972$ - V/1983 for Japan Absolute value of t statistics shown below each coefficient

for Japan, it does not have the theoretically predicted neyative sign

The coefficients on the distributed lag of exchange rate changes are statisticaly significam at the 5 percont level for the United states. Moreover, their sum $(-0.247)$ has the predicted negative sign. These results indicate that a 1 percentage-point increase (decrease) in the rate of growth of the exchange rate lears to a 0.25 percentage-point decline (rise) in the growth of U.S. nominal income after six quarters. Thus, if exchange rate movements reflect primarily changes in demand for domestic money, it appears that eco- 
Table 1

\section{Testing the Significance of Exchange Rate Changes}

\begin{tabular}{|c|c|c|c|}
\hline \multirow[b]{2}{*}{ Variabla } & \multicolumn{3}{|c|}{ Estimated Coefficients (lags) for } \\
\hline & United States & Germany & Japan \\
\hline Conotont & $\begin{array}{l}0,076 \\
(0,2)\end{array}$ & $\begin{array}{l}0.307 \\
0.21)\end{array}$ & $\begin{array}{l}0000 \\
072)\end{array}$ \\
\hline $\mathrm{MM}$ & $0.865^{*}(2)$ & $\left(3.307^{\circ}(6)\right.$ & $\begin{array}{l}0.6411(6) \\
(764)\end{array}$ \\
\hline 20 & $\begin{array}{l}0,340,4) \\
(1,96)\end{array}$ & $\begin{array}{l}0.213(8) \\
1411)\end{array}$ & $\begin{array}{l}0.227^{*}(3) \\
(3,15)^{\circ}\end{array}$ \\
\hline EF & $(0.25)$ & $\begin{array}{l}0.042 \\
(102)\end{array}$ & $\begin{array}{l}0.069^{\circ} \\
(2.68)\end{array}$ \\
\hline $\mathrm{EF}$ & $=0.092$ & & \\
\hline $\mathrm{EF}_{-2}$ & $\begin{array}{l}0.091 \\
(153)\end{array}$ & & \\
\hline$E F$ & $\begin{array}{c}0038 \\
(0,01)\end{array}$ & & \\
\hline$E F+$ & $\begin{array}{c}0.677^{\circ} \\
(249)\end{array}$ & & \\
\hline$E F_{-5}$ & $\begin{array}{r}0.005 \\
(139)\end{array}$ & & \\
\hline $\mathrm{EF}_{\leftrightarrow}$ & $\begin{array}{l}0.175^{\prime} \\
(2.32)\end{array}$ & & \\
\hline Jon FEF & 2.53 & 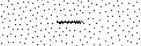 & + \\
\hline \multicolumn{4}{|c|}{ Summary statistics } \\
\hline$n^{2}$ & 0,26 & 042 & 078 \\
\hline SE & 424 & 354 & 320 \\
\hline DW & 210 & 218 & 211 \\
\hline
\end{tabular}

Statistically significant at the 5 percent tevel.

NOTE The sample periods are $1 / 1972,1 / 1984$ for the United States and Germany $1 / 1 / 972$ UV/1983 for lapan Absolute value of fostatistics shown below each coefficient

nomic activity in the United states is affected signifcantly by cumency substitution.

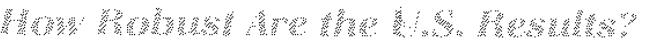

It is puzzling that currency bubstitution could have a significant impact in the United States but not in the other two countries. Afer all, the curency substitution argument is svmmetrical; that is, if the demand for one currency falls, the demand for another must rise. Consequently, since the Deutsche mark and the yen are the most likely substitutes for the U.S. dollar, one would expect that, if currency substitution has a significant impact on U.S. velocity, it should affect the velocity in Germany or Japan as well. Given that no other cvidenec of currency substitution cuuld be found examining the other two countries or using the other proxy variables, the U.S. result should be scrutinized more closely.

The approach taken here is to investigate this relationship over time. The experiment conducted was to estimate the US equation found in table 4 over the period IV/1972 to IV/1980, then add four quarters to the sample period until the original estimation period was reached." The results are reported in table $5 . " 1 \mathrm{~A}$ comparison of the results over time is quite revealing. The distributed lag of exchange rate changes is statistically significant at the 5 percent level onlv when the four quarters ending in IV/9983 are included in the sample." In fact, the summed coefficient is positive for the sample periods ending in IV/1980 and IV/1981 and heromes negative (the predicted sign) only when the four quarters ending in IV/1982 are added. These results support one of two possible scenarios: First. currency substitution has been important only during the past couple of vears. Second, recent exchange rate changes have spuriously captured events other than currency substitution.

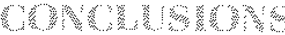

We have investigated the hypothesis that currency substitution affects the velocity of domestic monetary aggregates to the extent that anticipated policy outcomes mav not be realized. Using three variables to

\footnotetext{
20This is the furthest back into the sample period that we could go and still obtain reliable estimates. There are only 19 degrees of freedom in the first subperiod.

2:Glancing at table 5, one notices that the summed effect of money growth declines as the sample period is lengthened. While none of these summed effects is statistically different from one at the 5 percent level, this result probably indicates that the lag structure for money growth differs across estimation periods, while we have constrained the lag structure in each subperiod to be the one chosen for the entire period (11/1972-11/1984). For some corroborating evidence, see Batten and Thornton (1983).

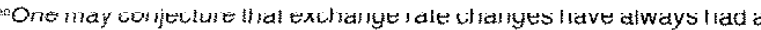
negative impact on economic activity, but were too small, until 1983 and 1984 , to be statistically significant. The data do not support this view, however. For example, from IV/1980 to IV/1982, the effective exchange rate rose at about a 17 percent annual rate and actually rose less rapidiy (at about a 10 percent rate) during 1983 and 1984
} 


\section{Table 5}

\section{Testing the Significance of Exchange Rate Changes in the United States}

\begin{tabular}{|c|c|c|c|c|c|}
\hline \multirow{2}{*}{$\begin{array}{l}\text { Estimated } \\
\text { Coeticients tor }\end{array}$} & \multicolumn{5}{|c|}{ Sample Period } \\
\hline & $11 / 1972-1$ V/1980 & I11972-IV1981 & 191972 - IV/1982 & $1 / 1972-1$ V1983 & $111972-141989$ \\
\hline Constant & $\begin{array}{l}-4.416 \\
(0.90)\end{array}$ & $\begin{array}{r}-4.650 \\
(1.22)\end{array}$ & $\begin{array}{r}-4.714 \\
(1.19)\end{array}$ & $\begin{array}{c}-1.625 \\
(0.47)\end{array}$ & $\begin{array}{l}0.376 \\
(0.12)\end{array}$ \\
\hline $2 M$ & $\begin{array}{l}1.734^{\prime} \\
(3.14)^{\prime}\end{array}$ & $\begin{array}{l}1.672^{\circ} \\
(3.90)^{\prime}\end{array}$ & $\begin{array}{l}1.425^{\circ} \\
(3.27)\end{array}$ & $\begin{array}{l}0.949^{\prime} \\
(3.03)^{\prime}\end{array}$ & $\begin{array}{l}0.865^{\circ} \\
(2.79)^{\prime}\end{array}$ \\
\hline 26 & $\begin{array}{r}0.309 \\
(1.50)\end{array}$ & $\begin{array}{l}0.346 \\
(1.04)\end{array}$ & $\begin{array}{l}\left.0.448^{\prime}\right) \\
(2.30)^{\prime}\end{array}$ & $\begin{array}{l}0.445^{\prime} \\
(2.40)\end{array}$ & $\begin{array}{l}0.340 \\
(1.96)\end{array}$ \\
\hline EF. & $\begin{array}{l}0.011 \\
(0.14)\end{array}$ & $\begin{array}{l}0.003 \\
(0.05)\end{array}$ & $\begin{array}{r}-0.027 \\
(0.44)\end{array}$ & $\begin{array}{r}-0.027 \\
(0.46)\end{array}$ & $\begin{array}{l}-0.015 \\
(0.25)\end{array}$ \\
\hline $\mathrm{Er} / 4$ & $\begin{array}{r}-0.020 \\
(0.27)\end{array}$ & $\begin{array}{r}-0.050 \\
(0.74)\end{array}$ & $\begin{array}{l}-0.002 \\
(0.93)\end{array}$ & $\begin{array}{r}-0.077 \\
(1.20)\end{array}$ & $\begin{array}{l}0.098 \\
(1.44)\end{array}$ \\
\hline $\mathrm{EF}_{1}$ & $\begin{array}{r}-0.032 \\
10.401\end{array}$ & $\begin{array}{l}-0.085 \\
(1.15)\end{array}$ & $\begin{array}{l}-0.101 \\
(1.55)\end{array}$ & $\begin{array}{r}-0.096 \\
(1.60)\end{array}$ & $\begin{array}{r}0.091 \\
(1.53)\end{array}$ \\
\hline $\mathrm{EF}_{-3}$ & $\begin{array}{l}0.046 \\
(0.60)\end{array}$ & $\begin{array}{l}0.084 \\
(1.11)\end{array}$ & $\begin{array}{l}0.023 \\
(0.35)\end{array}$ & $\begin{array}{l}0.005 \\
(0.08)\end{array}$ & $\begin{array}{l}0.038^{\circ} \\
(2.49)\end{array}$ \\
\hline EF. & $\begin{array}{l}-0.037 \\
(0.44)\end{array}$ & $\begin{array}{l}-0.077 \\
(0.97)\end{array}$ & $(1.40)$ & $\begin{array}{r}0.149^{\circ} \\
(2.10)^{\prime}\end{array}$ & $\begin{array}{c}-0.167^{\circ} \\
(2.49)\end{array}$ \\
\hline $\mathrm{EF}_{H_{3}}$ & $\begin{array}{l}0.050 \\
(0.62)\end{array}$ & $\begin{array}{r}-0.016 \\
(0.20)\end{array}$ & $=-0.099$ & $\begin{array}{r}-0.078 \\
(1.11)\end{array}$ & $\begin{array}{r}-0.095 \\
(1.39)\end{array}$ \\
\hline $\mathrm{EF}, 6$ & $\begin{array}{l}0.180 \\
(2.08)^{\prime}\end{array}$ & $\begin{array}{l}0.180 \\
(2.00)\end{array}$ & $\begin{array}{l}0.153 \\
(1.85)\end{array}$ & $\begin{array}{l}0.136 \\
(1.70)\end{array}$ & $\begin{array}{l}0.175^{\circ} \\
(2.32)\end{array}$ \\
\hline Joint $F(E F)$ & 0.66 & 0.81 & 1.52 & $2.41^{\prime}$ & $253^{\circ}$ \\
\hline \multicolumn{6}{|c|}{ Summary statistics } \\
\hline $\bar{n}^{2}$ & 0.25 & 032 & 0.35 & 0.29 & 0.26 \\
\hline$s t$ & 3.85 & 4.01 & 4.22 & 4,2 & 4.24 \\
\hline ow & 2.47 & 267 & 2.13 & 212 & 2.10 \\
\hline
\end{tabular}

Statictioally significant at the 5 porcont lovel.

NOTE Absolute value of -statistics shown below each coefficient

measure currency substitution, we could find no statistical support for the hypothesis in either Germany or Japan. We did find some support for the United States when exchange rate movements were used to proxy for currency substitution. When this result was subjected to a closer examination, however, the data indicated either that currency substitution is only a very recent phenomenon, or that recent exchange rate movements have captured effects other than those of currency substitution. Consequently, the variables offered in the literature and used here to estimate the extent of currency substitution provide no compelling statistical suppont for its existence.

\section{等等}

Artus, Jacques R., and Anne Kenney McGuirk. "A Revised Version of the Multilateral Exchange Rate Model," IMF Staff Papers (June 1981), pp. $207-309$

Batten, Dallas S., and R. W. Hate". "The Relative Impact of Mone tary and Fiscal Actions on Economic Activity: A Cross-Country Comparison," this Review (January 1983), pp. 5-12.

"Currency Subst"ution: A Test of Its Importance," this Review (Auqust/September 1984a). op. 5-12.

"The Impact of International Factors on U.S. Inflation: An Empirical Test of the Currency Substitution Hypothesis," Federal Reserve Bank of St. Louis Research Paper No. 84-025 (1984w). 
Batten, Dallas S., and Mack Ott. "The Interrelationship of Monetary Policies Under Floating Exchange Rates," Joumal of Money, Credit and Banking (February 1985), pp. 103-10.

Batten, Dallas S., and Daniel L. Thornton. "Polynomial Distributed Lags and the Estimation of the St. Louis Equation," this Review (April 1983), pp. 13-25.

"How Robust Are the Policy Conclusions of the St. Louis Equation?: Some Further Evidence," this Review (June/July 1984), pp. 26-32.

Brittain, Bruce. "International Currency Substitution and the Apparent Instability of Velocity in Some Western European Countries and in the United States," Journal of Money, Credit and Banking (May 1981), pp. 135-55.

Goldstein, Henry N., and Stephen E. Haynes. "A Critical Appraisal of McKinnon's World Money Supply Hypothesis," American Economic Review (March 1984), pp. 217-24.
McKinnon, Ronald I. "Currency Substitution and Instability in the World Dollar Standard," American Economic Review (June 1982), pp. 320-33.

An International Standard for Monetary Stabilization (Institute for International Economics, 1984).

Miles, Marc A. "Currency Substitution, Flexible Exchange Rates, and Monetary Independence," American Economic Review (June 1978), pp. 428-36.

Mussa, Michael. "The Fole of Official Intervention," Occasional Paper No. 6, Group of Thirty (1981).

Radcliffe, Christopher, Arthur D. Warga, and Thomas D. Willett. "Currency Substitution and Instability in the World Dollar Standard: Comment," American Economic Review (December 1984), pp. $1129-31$.

Spinelli, Franco. "Currency Substitution, Flexible Exchange Rates, and the Case for International Monetary Cooperation," IMF Staff Papers (December 1983), pp. 755-83.

Stockman, Alan C. "A Theory of Exchange Rate Determination," Joumal of Political Economy (August 1980), pp. 673-98. 